\title{
THE GENUS CESTRUM IN GUATEMALA ${ }^{1}$
}

\author{
C. V. MORTON
}

Through THE courtesy of the Arnold Arboretum I have been enabled to study a collection of Solanaceae made in Guatemala by Dr. Alexander F. Skutch, who is to be congratulated not only upon the keenness of his collecting but the excellence of his specimens as well. Inasmuch as six new species of Cestrum were represented in the collection, the following short synopsis of the genus in Guatemala was prepared. However, the recent appearance of a comprehensive monograph of the genus by Dr. P. Francey ${ }^{2}$ has necessitated the rewriting of certain portions in order to include the new species described by him. One of the new species collected by Dr. Skutch has been described on other material as $C$. guatemalense Francey. No other changes have been found necessary, except that I follow Dr. Francey in referring certain specimens, which I had previously called $C$. megalophyllum Dunal, to $C$. Baenitzii Lingelsh. These two species are, admittedly, too close and should perhaps be considered only varietally distinct.

The species of Guatemala are all of restricted altitudinal range, four (C. Baenitzii, C. panamense, $C$. scandens, and $C$. nocturnum) being wide-ranging species found from sea-level up to 1000 meters altitude, rarely up to 1500 in $C$. nocturnum. Eight ( $C$. dumetorum, C. lanatum, C. aurantiacum, C. elegantissimum, C. Skutchii, C. Franceyi, C. cobanense, and $C$. luteovirescens) are species of middle elevations (1000 to 2000 meters) and are, except the first two, confined to Guatemala. Five (C. fraternum, C. formosum, C. guatemalense, C. dasyanthum, and $C$. Regelii) are montane species, endemic in western Guatemala and Chiapas.

In addition to the material of the genus in the Arnold Arboretum and the U. S. National Herbarium, I have had also the advantage of studying the Mexican and Central American specimens in the Gray Herbarium, the loan of which is gratefully acknowledged.

${ }^{1}$ Published by permission of the Secretary of the Smithsonian Institution.

${ }^{2}$ Candollea 6: 46-398 (1935) and 7: 1-132 (1936). 


\section{Key to THE Species}

Stems, leaves and calyces stellate-tomentose ........... C. lanatum. Stems, leaves and calyces glabrous or hairy, the hairs sometimes branched but not stellate.

Corolla tube hairy .................... C. dasyanthum. Corolla tube glabrous.

Filaments appendiculate.

Corolla tube $9-11 \mathrm{~mm}$. long ..............5. C. dumetorum. Corolla tube $15-23 \mathrm{~mm}$. long.

Corolla orange; calyx lobes prominent, mucronate....

2. C. aurantiacum.

Corolla greenish-yellow, white or purplish; calyx lobes minute, deltoid or rounded.

Leaves linear or linear-lanceolate, not more than 2.6 $\mathrm{cm}$. wide, usually 4 to 7 times as long; flowers sessile, borne in fascicles at the ends of short branches.

Calyx lobes deltoid; leaves linear-lanceolate ....

14. C. luteovirescens.

Calyx lobes low and rounded; leaves linear ..13. C. Skutchii.

Leaves not linear or linear-lanceolate, $3 \mathrm{~cm}$. wide or more, 2-4 times as long; flowers sessile or pedicellate, borne in loose panicles.

Leaves dimorphic, those in the axils minute, orbicular, sessile and stipule-like; larger leaves glabrous, with 17-20 pairs of primary veins; calyx and rhachis purple ......12. C. elegantissimum.

Leaves not dimorphic, the larger with not more than 13 pairs of primary veins; calyx and rhachis green.

Filaments and appendages densely pilosulous; calyx $3.5-4 \mathrm{~mm}$. long. Leaves with at least a few hairs on midrib and primary veins.

Flowers with long pedicels and short peduncles

7. C. fraternum.

Flowers with very short pedicels and long peduncles ................. C. Franceyi

Filaments and appendages glabrous; calyx $3 \mathrm{~mm}$. long or less.

Mature stems and petioles densely puberulous; mature leaves puberulous on the midrib beneath .................. C. cobanense.

Mature stems, petioles and leaves glabrous.

Appendage of the filament deeply bipartite; inflorescences terminal, dichotomously branched, the flowers pedicellate ......

10. C. evanidum. 
Appendage of the filament entire or merely notched; inflorescences chiefly axillary, not dichotomous, the flowers sessile ....

11. C. nocturnum.

Filaments exappendiculate.

Leaves hairy beneath. Montane species.

Calyx lobes long, subulate, green; corolla bright yellow

Calyx lobes short, broadly deltoid, purple; corolla yel-

1. C. Regelii.

lowish, tinged with purple .........19. C. guatemalense.

Leaves glabrous beneath.

Corolla bright yellow; flowers relatively long-pedicellate; montane species.

Corolla tube $2-2.5 \mathrm{~mm}$. broad near the middle, not over 3 times as long as the calyx, gradually enlarged upwardly ................. formosum.

Corolla tube about $1 \mathrm{~mm}$. broad near the middle, at least 5 times as long as the calyx, abruptly expanded near the summit ........... 18 . pacayense.

Corolla pale yellowish-green; flowers sessile or subsessile, corolla tube not over $1 \mathrm{~mm}$. broad near the middle, at least 5 times as long as the calyx. Lowland species.

Leaves attenuate at base, broadest above the middle

Leaves rounded or nearly acute at base, broadest

6. C. Baenitzii. below the middle.

Corolla small, the tube not more than $14 \mathrm{~mm}$. long, the lobes $4 \mathrm{~mm}$. long ............ C. panamense. Corolla large, the tube $17-20 \mathrm{~mm}$. long, the lobes 7-9 mm. long ................ scandens.

1. Cestrum Regelii Planchon in Fl. des Serres, 9:229, pl. 946 (1854).

Habrothamnus aurantiacus Regel, Ind. Sem. Hort. Turic. 1850 Coll. 4. note, fide Walp. Ann. 3:176 (1852). Not Cestrum aurantiacum Lindl. (1844).

Cestrum chiapense Brandegee in Univ. Calif. Publ. Bot. 6:192 (1915).

Cestrum jacaltenanginum Loesener in Verh. Bot. Ver. Brandenb. 65: 98 (1923).

Francey has attempted to maintain these three species as distinct, but the characters given to separate them seem not to hold in the material at hand. An additional species, which should perhaps have been included in the key, is Cestrum psittacinum Stapf (Curtis Bot. Mag. 152: pl. 9158. 1926), founded on cultivated material of unknown origin. This is very likely a native of Guatemala, for its relationship with C. Regelii is close. It differs in having bicolorous corollas (the tube 
orange, the lobes green), in having shorter calyx lobes, and also in having the flowers borne in non-bracteate racemes.

I have seen the following specimens of $C$. Regelii: Chiapas: Cerro del Boqueron, Purpus 7170 (type collection of $C$. chiapense). GuateMaLA: Plains near Tecpam, Chimaltenango, Skutch 488. Jacaltenango, Huehuetenango, Seler 2641 (type collection of $C$. jacaltenanginum).

2. Cestrum aurantiacum Lindley in Bot. Reg. 30 : Misc. 71 (1844). Cestrum chaculanum Loesener in Verh. Bot. Ver. Brandenb. 65:97 (1923).

Cestrum paucinervium Francey in Candollea, 6:101 (1935). Synon. nov.

Cestrum aurantiacum var. chaculanum Francey in op. cit. 104. Synon. nov.

Francey has recognized several varieties of $C$. aurantiacum, as well as a new species (C. paucinervium) of this alliance. Of the latter I have examined a specimen of the type collection, and have not been able to separate it from typical $C$. aurantiacum either by leaves or inflorescence. The varieties are based on the size of leaves, petioles, and calyces. These differences seem artificial; but when the relative length of calyx and corolla is used as a means of separation, all the Guatemalan specimens are seen to have the corolla three times the length of the calyx or more. On the other hand, all the Costa Rican specimens have a corolla not more than twice as long as the calyx. This consistency in such an important character, coupled with the geographic separation of the two, shows that Klotzsch was very likely correct in considering that the Costa Rican plants represent a distinct species, Cestrum Warscewiczii.

In Guatemala Cestrum aurantiacum is a common species of middle elevations from 1300 to 2000 meters. The berries (not seen by Francey) are white, ellipsoidal, and very large. I have seen the following specimens from Guatemala, not cited by Francey: Coban, Tuerckheim 26a, 8433. Guatemala, Tonduz 625; Hayes s. n. Santa Rosa, Cook \& Doyle 232. Santa Maria, Kellerman 5579. Volcán Fuego, Donnell Smith 2678. Without locality, Heyde 95. Santa María de Jesus Nepto, Quetzaltenango, Skutch 893.

3. Cestrum lanatum Martens \& Galeotti in Bull. Acad. Brux. $\mathbf{1 2}^{2}$ : $146(1845)$.

A distinctive species, found in Guatemala at elevations of 1200 to 1500 meters.

4. Cestrum dasyanthum Donnell Smith in Bot. Gaz. 23:11 (1897). 
A species of apparently restricted range. I have examined the following collections: Between San Martín and Todos Santos, Huehuetenango, Nelson 3622 (type); Seler 2632. San Juan Atitlán, Huehuetenango, Skutch 1157, 1178.

5. Cestrum dumetorum Schlechtendal in Linnaea, 7:61 (1832).

A widely dispersed species, found in southern Guatemala in the Departments of Guatemala, Santa Rosa, and Amatitlán, at altitudes of 1000 to 1500 meters.

6. Cestrum Baenitzii Lingelsheim in Fedde, Rep. Spec. Nov. 7 : 248 (1909).

Following Hemsley, the specimens cited below have previously been identified as Cestrum macrophyllum Vent., but that species has appendiculate filaments and is more closely allied to $C$. laurifolium. In Guatemala $C$. Baenitzii is found only near sea-level in the eastern part. The following collections have been studied. Quiriguá, Izabal, Standley 24481, 24533. Cubilquitz, Alta Verapaz, Tuerckheim 8558. Finca Sepacuité, Alta Verapaz, Cook \& Griggs 845.

7. Cestrum fraternum Morton, sp. nov.

Frutex $2.4 \mathrm{~m}$. altus; rami teretes, juniores puberuli, mox glabri; petioli $2.2 \mathrm{~cm}$. longi, glabri; lamina foliorum elliptica, usque ad $16.5 \mathrm{~cm}$. longa et $5.5 \mathrm{~cm}$. lata, membranacea, apice acuminata, basi acuta vel obtusa, supra glabra, subtus costa et venis primariis parce puberula, venis primariis 10-13-jugis; inflorescentiae terminales et axillares, rhachibus gracilibus puberulis, bracteis minutis caducis, pedicellis ca. $3 \mathrm{~mm}$. longis; calycis tubus viridis, campanulatus, ca. $3.5 \mathrm{~mm}$. longus et $2 \mathrm{~mm}$. latus, glaber, lobis minutis late deltoideis plus minusve mucronatis ca. $0.5 \mathrm{~mm}$. longis margine puberulis; corollae tubus pallide flavidus, interdum externe purpureo-tinctus, glaber, ca. $20 \mathrm{~mm}$. longus, basi ca. 1.8 $\mathrm{mm}$. latus, sursum sensim ampliatus sed non inflatus, fauce non contractus, ca. $5 \mathrm{~mm}$. diam., lobis reflexis late ovatis, ca. $4 \mathrm{~mm}$. longis et 3 $\mathrm{mm}$. basi latis apice longe mucronatis; filamentorum pars libera ca. 3.5 $\mathrm{mm}$. longa, glabra, basi appendiculata appendicula minuta rotundata pilosula, filamentorum pars adnata pilosula; stylus $18 \mathrm{~mm}$. longus, paullo exsertus; fructus ignotus.

Type in the U. S. National Herbarium, no. 1,642,529, collected in moist thicket at Nebaj, Dept. of Quiché, Guatemala, altitude 2340 meters, Nov. 16, 1934, by A. F. Skutch, no. 1682 (isotype in Herb. Arnold Arb.).

8. Cestrum Franceyi Morton, nom. nov. 
Cestrum pedunculatum Francey in Candollea, 7:66 (1936). Not Sessé \& Mocino (1894).

I have seen no material of this species other than two sheets of the type collection, Tuerckheim 833, from Pansamala.

9. Cestrum cobanense Francey in Candollea, 6: 372 (1935).

I have examined two sheets of the type collection (Tuerckheim II. 2372 ) and find this to be a well-marked species.

10. Cestrum evanidum Morton, sp. nov.

Frutex gracilis; rami teretes, juniores puberuli, mox glabri; petioli usque ad $1.4 \mathrm{~cm}$. longi, glabri; folia juniora utrinque puberula, mox glabrata; lamina ovato-lanceolata, usque ad $13 \mathrm{~cm}$. longa et $5 \mathrm{~cm}$. lata, membranacea, apice acuminata, basi rotundata, venis secundariis 6-10-jugis; inflorescentia terminalis, pedunculata, dichotome ramosa, rhachibus gracilibus, glabris, viridibus, ebracteatis; calyx viridis, campanulatus, minimus, ca. $2 \mathrm{~mm}$. longus, glaber, 5-costatus, basi plus minusve longe stipitato-pedicellatus, lobis parvis deltoideis aequalibus; corolla viridis, glabra, tubo angusto $20-23 \mathrm{~mm}$. longo basi ca. $0.6 \mathrm{~mm}$. lato sursum sensim ampliato et usque ad $3 \mathrm{~mm}$. lato, fauce non contracto, lobis lanceolatis ca. $5 \mathrm{~mm}$. longis; filamenta recta, glabra, appendiculata, appendicula magna bipartita glabra.

Type in the U. S. National Herbarium, no. 1,642,528, collected at Finca Moca, Dept. Suchitepequez, Guatemala, alt. 960 meters, Jan. 7, 1935, by A. F. Skutch, no. 2071A (isotype in Herb. Arnold Arb.).

The following specimen, distributed as Cestrum nocturnum, is also referred to $C$. evanidum: Acatepeque, Dept. Zacatepequez, Guatemala, alt. 1290 meters, Donnell Smith 2681.

The closest relationship of Cestrum evanidum is perhaps with $C$. nocturnum, a species which, in spite of its wide range, is relatively constant in appearance and essential characters. The inflorescences of $C$. nocturnum are chiefly axillary, are not dichotomous, and are usually without an obvious peduncle, characters which easily distinguish that species from $C$. evanidum, which has strictly terminal, dichotomously branched, pedunculate inflorescences. The calyx of the latter is obviously 5-ribbed and rather long-stipitate at base, but that of $C$. nocturnum is ribless and usually almost sessile. The filament appendages of $C$. nocturnum are sometimes inconspicuously notched, but are never deeply partite into two subulate lobes as in C. evanidum.

11. Cestrum nocturnum Linné, Sp. Pl. 191 (1753).

A common lowland species occurring from sea-level up to 1500 meters elevation. 


\section{Cestrum elegantissimum Morton, sp. nov.}

Frutex $3.6 \mathrm{~m}$. altus; rami teretes, glabri; folia dimorpha; petioli usque ad $1.2 \mathrm{~cm}$. longi, glabri, supra canaliculati; lamina foliorum majorum oblongo-lanceolata, usque ad $16 \mathrm{~cm}$. longa et $5 \mathrm{~cm}$. lata, papyracea, apice longe et acriter acuminata, basi acuta vel obtusa vel rotundata, glabra, venis primariis utrinque elevatis 17-20-jugis ex costa angulo fere $90^{\circ}$ egredientibus subrectis marginem versus furcatis, ramulis alteris utroque latere conjunctis; folia minora axillaria minuta, auriculiformia, stipuliformia, orbicularia, usque ad $1 \mathrm{~cm}$. longa, petiolo nullo; inflorescentia terminalis, usque ad $13 \mathrm{~cm}$. longa et $11 \mathrm{~cm}$. lata, paniculata, ramulis infimis basi foliis auriculiformibus suffultis, rhachibus atropurpureis gracilibus puberulis, pilis hyalinis numerosis multiseptatis flaccidis interdum fortasse glanduliferis, bracteis atropurpureis linearibus vel lineari-subulatis parce puberulis plus minusve persistentibus, pedicellis brevibus $1-1.5 \mathrm{~mm}$. longis crassiusculis parce puberulis; calyx atropurpureus, tubo cum pedicello continuo poculiformi ca. $2.5 \mathrm{~mm}$. longo et $2 \mathrm{~mm}$. lato extus pilos paucos gerente, lobis 5 regularibus deltoideis minutis ca. $0.8 \mathrm{~mm}$. longis acuminatis margine dense puberulis; corolla flavescenti-viridis, haud purpurascens, tubo glabro ca. $21 \mathrm{~mm}$. longo anguste tubuloso basi recto ca. $1.5 \mathrm{~mm}$. lato, faucem versus paullo inflato ca. $2.5 \mathrm{~mm}$. lato, fauce contracto ca. $2 \mathrm{~mm}$. lato glabro, lobis patulis lanceolatis ca. $6 \mathrm{~mm}$. longis et ca. $2 \mathrm{~mm}$. latis acutis marginibus introflexis albis externe puberulis; filamenta (pars libera) $3 \mathrm{~mm}$. longa, glabra, basi perspicue appendiculata appendiculis obtusis vix pilosulis, filamentorum parte adnata pilos paucos gerente; ovarium glabrum, perspicue stipitatum; stylus $18.5 \mathrm{~mm}$. longus, glaber, sursum granuliferus; baccae non suppetunt.

Type in the U. S. National Herbarium, no. 1,642,527, collected in forest at Finca Moca, Dept. of Suchitepequez, Guatemala, altitude 1320 meters, Jan. 7, 1935, by A. F. Skutch, no. 2071 (isotype in Herb. Arnold Arb.).

\section{Cestrum Skutchii Morton, sp. nov.}

Frutex $1.5 \mathrm{~mm}$. altus; rami teretes, glabri; petioli usque ad $1 \mathrm{~cm}$. longi, glabri; lamina foliorum linearis, usque ad $16 \mathrm{~cm}$. longa et 2.6 $\mathrm{cm}$. lata, membranacea, apice longe acuminata, basi acuta vel obtusa, glabra, venis primariis 15-20-jugis, marginem versus anastomosantibus, utrinque paullo elevatis; inflorescentiae axillares (et terminales?), densae, subspicatae, 3-9-florae, rhachibus atropurpureis glabris crassiusculis, bracteis atropurpureis linearibus fere glabris, pedicellis obsoletis ca. $0.5 \mathrm{~mm}$. longis glabris; calycis tubus atropurpureus, tubulosus, $3.4-5 \mathrm{~mm}$. longus, $2.25 \mathrm{~mm}$. latus, glaber, lobis minutis rotundatis 0.4 
mm. longis margine puberulis; corollae tubus albus, plus minusve purpureo-tinctus, glaber, $21 \mathrm{~mm}$. longus, anguste tubulosus, basi ca. 1.5 mm. latus, sursum gradatim ampliatus sed non ventricosus, fauce non contractus, ca. $3.75 \mathrm{~mm}$. latus, lobis albis vix purpureo-tinctis recurvatis late ovatis ca. $5 \mathrm{~mm}$. longis et $3.75 \mathrm{~mm}$. latis, margine introflexo latissimo externe puberulo; filamentorum pars libera $4 \mathrm{~mm}$. longa, glabra, basi perspicue appendiculata appendiculis obtusis pilosulis, pars adnata pilosula; ovarium glabrum, stipitatum; stylus ca. $1.9 \mathrm{~cm}$. longus; baccae non suppetunt.

Type in the U. S. National Herbarium, no. 1,642,526, collected in second growth thicket on the Volcán Zunil, Dept. of Quezaltenango, Guatemala, alt. 1710 meters, Aug. 8, 1934, by A. F. Skutch, no. 988 (isotype in Herb. Arnold Arb.).

14. Cestrum luteovirescens Francey in Candollea, 6: 349 (1935).

I have studied three specimens of the type collection, Donnell Smith 2679 from Capetillo.

15. Cestrum panamense Standley in Jour. Wash. Acad. 15: 460 (1925).

Cestrum racemosum var. panamense Francey in Candollea, 6:274 (1935).

I am inclined to treat the present species as valid, in spite of its reduction by Francey to a variety of the Peruvian $C$. racemosum. In addition to the characters by which Francey separates the two, it may be pointed out that $C$. racemosum is a shrub only about a meter high, and that $C$. panamense is always a tree and often a very large one, up to 24 meters high, with a trunk three-fourths of a meter in diameter.

I have seen the following collections: Colomba, Dept. Quetzaltenango, Skutch 2000, 2024. Uaxactun, Petén, Bartlett 12175, 12743. Quiriguá, Izabal, Standley 23767, 24144. San Carlos, Rojas 207. Telemán, Alta Verapaz, Donnell Smith 1672. Near Patalul, Kellerman 5821.

16. Cestrum scandens Vahl, Eclog. Amer. 1: 24 (1796).

Cestrum perilambanon Loesener in Verh. Bot. Ver. Brandenb. 65: 98 (1923).

I have seen two collections from Guatemala: Chiquimula, altitude 165 meters, Seler 3381 (type collection of $C$. perilambanon). Cuyuta, Dept. Escuintla, 60 meters altitude, Donnell Smith 2081.

17. Cestrum formosum Morton, sp. nov.

Frutex gracilis, erectus, $4.5 \mathrm{~m}$. altus; rami teretes, glabri; petioli satis longi, 17-23 mm. longi; lamina foliorum elliptica, usque ad $9 \mathrm{~cm}$. longa 


\section{$2 \mathrm{BHL}$ Biodiversity Heritage Library}

Morton, C. V. 1936. "The genus Cestrum in Guatemala." Journal of the Arnold Arboretum 17(4), 341-349. https://doi.org/10.5962/bhl.part.7056.

View This Item Online: https://www.biodiversitylibrary.org/item/33593

DOI: https://doi.org/10.5962/bhl.part.7056

Permalink: https://www.biodiversitylibrary.org/partpdf/7056

\section{Holding Institution}

Missouri Botanical Garden, Peter H. Raven Library

\section{Sponsored by}

Missouri Botanical Garden

\section{Copyright \& Reuse}

Copyright Status: In copyright. Digitized with the permission of the rights holder.

Rights Holder: Arnold Arboretum of Harvard University

License: http://creativecommons.org/licenses/by-nc-sa/3.0/

Rights: https://biodiversitylibrary.org/permissions

This document was created from content at the Biodiversity Heritage Library, the world's largest open access digital library for biodiversity literature and archives. Visit BHL at https://www.biodiversitylibrary.org. 